\title{
ASSESSMENT THE SYNCHRONY BETWEEN UTERINE STATUS AND HORMONAL PROFILES IN MODIFIED OVSYNC PROTOCOLS IN RELATION TO FERTILITY IN BUFFALOES
}

\author{
Adel A. Ramoun ${ }^{1 *}$, Ismail I. EL- Kon ${ }^{1}$, Essam A. Almadaly ${ }^{1}$, Aly M. Aly², Hasballah A. \\ Abo EL- Ghate 3
}

\begin{abstract}
${ }^{1}$ Department of Theriogenology, Faculty of Veterinary Medicine, Kafrelsheikh University, Kafrelsheikh, 33516, Egypt, ${ }^{2}$ General Authority for Veterinary Services, Kafr EL-Sheikh, Egypt, ${ }^{3}$ Mahallet Mousa Buffalo Research Station, Animal Production Research Institute, Agriculture, Research Center, Egypt
\end{abstract}

*Corresponding author, E-mail: ramoun2004@yahoo.com

\begin{abstract}
A total of 36 pluriparous buffaloes were used to study the uterine morphometry in response to serum estradiol concentrations and associated estrogen receptors (ERs) expression in modified ovsync protocols. The buffaloes were assigned to St-ovsync, CIDR-sync and Insulin-sync ( $n=12$ for each). The St-ovsync consisted of two IM injections of $20 \mu \mathrm{g}$ buserelin on the Day $0(\mathrm{GnRH} 1)$ and on the Day $9(\mathrm{GnRH} 2)$ and an IM injection of $500 \mu \mathrm{g}$ of Cloprostenol sodium (Estrumate) on Day 7. Buffaloes in CIDR-sync and Insulin-sync protocols were treated as in the St-Ovsync protocol in addition to intravaginal insertion of CIDR from Day 0 to 7 in CIDR-sync and SC injection of Insulin at a dose of $0.25 \mathrm{lU} / \mathrm{kg}$ body weight on Days 7, 8 and 9 in Insulin-sync. Blood samples were collected and the uterine wall thickness (UWT) was simultaneously measured by transrectal ultrasonography on Days 0, 3, 5, 7, 8 and 9. Endometrial biopsies samples were collected from five buffaloes in each group to quantify the abundance of estrogen receptors. The UWT on Days 3 and 5 decreased significantly $(P<0.05)$ while serum $P_{4}$ concentration on Day 3 was significantly $(P<0.05)$ increased in eventually diagnosed pregnant (EDP) buffaloes in CIDR-sync compared with their counterparts in either St-Ovsync or Insulinsync. On Day 9, although there was a decrease in serum $\mathrm{E}_{2}$ concentration in CIDR-sync compared with either St-Ovsync or Insulin-sync in EDP buffaloes, there was an increase $(\mathrm{P}<0.05)$ in the ER mRNA expression in CIDR-sync compared with St-Ovsync. It could be concluded that modifying the St-Ovsync by $\mathrm{P}_{4}$ supplementation through intravaginal insertion of CIDR from Day 0 to 7 or by SC injection of insulin on the Days 7, 8 and 9, could modulate uterine morphometry such conductive to proper fertility response.
\end{abstract}

Key words: Buffaloes, ERa; uterine wall thickness; Ovsync

\section{Introduction}

Optimal uterine environment at the time of FTAI, especially in cows induced to ovulate immature follicles in ovsync programs, is critical to establish and maintain pregnancy (1). The variation in the fertility status of cows kept under the same nutritional and environmental conditions may result from the different response 
of the uterus to steroid hormones during the periovulation time (2). Adequate rise in the proestrous estradiol ( $\left.\mathrm{E}_{2}\right)$ following pre-exposure to progesterone $\left(\mathrm{P}_{4}\right)$ prepares the uterus for embryonic development and establishment of pregnancy $(3,1,2$, and 4$)$. The growth and regression of endometrium are synchronized through changes in the circulating and/or local levels of $\mathrm{E}_{2}$ and $\mathrm{P}_{4}(5)$.

Endometrial thickness increases during proestrous and reach maximal thickness on the day before ovulation and decreases throughout diestrous $(6,7)$. Suboptimal uterine environment induced by low level of estrogen during proestrous and progesterone during diestrous decreases infertility in dairy cows (8). Infertility in cows induced to ovulate immature follicles especially in Ovsync-TAI program may be attributed to suboptimal uterine function caused by low steroids at the periovulation time $(9,10$, and 1). Not only the availability of steroid hormones with optimal levels in the peripheral blood is adequate to produce the desired effect on the uterus but binding to their specific nuclear receptors is critical (11). The effect of steroid hormones on the uterus depends on tissue and cell specific expression of steroid receptors (12) which reach maximum levels around the time of heat $(13,14)$. E2 modulates the expression of its receptors and their function at the cellular level in such way that increase the rate of mitosis and tissues edema (15). OvsyncTAI programs either GnRHbased or estradiolbased, are used nowadays to improve the reproductive performance of dairy cows $(16,17)$. In estradiol - based TAI programs, the exogenous $\mathrm{E}_{2}$, in addition to inducing $\mathrm{GnRH} / \mathrm{LH}$ surges, it modulates uterine environment. However, the relatively small follicles that might be present prior to second GnRH in case of GnRHbased Ovsync-TAI program may not produce adequate amount of estradiol sufficient to modulate uterine environment such compatible to support pregnancy (1). The US-measured uterine wall thickness (UWT) and horn diameter could be utilized to test if the uterus has been exposed to adequate concentration of steroid hormones compatible with optimal fertility (18).
Scoring the uterine status prior to the breeding time could be useful for predicting fertility in many species including human. Amongst the methods used to evaluate uterine status are cytology of uterine secretion, ultrasonographic (US) examination and uterine biopsy (19). The current study tests the hypothesis that if the USmeasured UWT together with the uterine biopsy could be used to predict fertility of buffaloes subjected to modified ovsync programs. Souza et al (2014) (4) utilized endometrial thickness as a predictor of fertility in high producing dairy cows. They concluded that an endometrial thickness less than $7 \mathrm{~mm}$ is predictive to failure of conception in dairy cows. However, the associated steroid hormones profile together with estrogen receptors were quantified to correlate between hormonal profiles and uterine morphometry.

Thus, the current study was designed to match US-measured UWT with steroid hormones profiles together with estrogen receptors expression in the endometrial biopsy sample in an attempt to utilize UWT as a predicting measure of fertility following application of modified CIDR- and Insulin- ovsyncs in buffaloes.

\section{Materials and methods}

\section{The animals}

The study was performed in Mahallet Mousa Buffalo Research Station, affiliated to Animal Production Research Institute, present in Kafrelsheikh province in the northern of the Nile Delta, Egypt. The experiment was performedfrom April to October which coincides withlow breeding season in the Egyptian buffaloes.

A total of 36 pluriparous cyclic Murrah buffaloes having a parity of 2- 4 and an average body condition score of 2.75 to 3.50 (Scoringsystem was $1=$ thin to $5=$ fat) were used to carry out this study. Buffaloes were kept indoors throughout the year in yards where $50 \%$ of the yard area was sheltered. They hadfree access to water. They were milked twice daily and received a diet that covered both maintenance and production requirements according to the Recommendation of Animal Production Research Institute (APRI, 1997unpublished data). 
All animals were cyclicand had healthy genital tract on the basis oftransrectal US scanning of the reproductive system. The cyclic activity was assessed onthe basis of detecting a corpus luteum in eitherof two transrectal US examinations of ovariesdone at 10 days' interval (from Day -10 to Day 0). Day 0 was the day of the first GnRH injection.

\section{Experimental design}

Buffaloes $(\mathrm{N}=36)$ were randomly assigned to three treatment protocols (12 each): standard ovsync (control group, St-Ovsync), modified CIDR-sync (CIDR-sync) and modified Insulinsync (Insulin-sync). Each buffalo in the StOvsync group received IM injections of $20 \mu \mathrm{g}$ buserelin acetate (GnRH agonist,5 $\mathrm{ml}$ Receptal ${ }^{\circledR}$, Intervet Company, Holland) on the Day 0 (GnRH1), $500 \mu \mathrm{g}$ of Cloprostenol sodium (PGF2 $\alpha$ analogue, $2 \mathrm{ml}$ Estrumate ${ }^{\circledR}$, Coopers, Schering Plough Company, England) on the Day 7 and a 2nd dose of GnRH agonist similar to GnRH1, on the Day 9 (GnRH2). Buffaloes in the CIDR-syncgroup were treated as in St-ovsync in addition to intravaginal insertionof CIDR (Controlled Internal Drug Release, it contains $1.38 \mathrm{gm}$ of progesterone, Pfizer Company, New Zealand) from the Day 0 to the Day 7. Buffaloes in Insulin-sync were also treated as St-Ovsync in addition to daily s/c injection of insulin (biphasic isophane insulin,0.25 IU / $\mathrm{kg}$ of B.W, Mixtard $30 \mathrm{HM} \AA$, Nova, Nordisk, Bagsvared, Denmark) on the Days 7, 8 and 9. Each $1 \mathrm{ml}$ of Mixtard $30 \mathrm{HM} \AA$ contain $30 \mathrm{IU}$ of soluble and $70 \mathrm{IU}$ of isophane biosynthetic human insulin. Buffaloes in all groupswere bred at $16 \mathrm{hr}$ after the second GnRH treatment.

\section{Ultrasonographic scanning}

US examination was conducted by using portable ultrasound device (ULTRASCAN MODEL DP 30 VET, Shanghai International Holding Crop GmbH, Europe) equipped with multifrequency $(3-10 \mathrm{MHz}$ ) linear probe. For transrectal scanning of the uterus, the probe while being carried in the palm of the hand was guided into the rectum. The uterus was identified then the probe was transversely placed on the base of each uterine horn at $3 \mathrm{~cm}$ cranial to the intercornual ligament. The UWT was measured by electronic calipers in the cross section of the frozen image. The UWT was measured as the distance between the edge of uterine lumen to the external edge of the perimetrium. The UWT was estimated for each uterine horn then the average value of the two horns was calculated for each cow. The UWT was measured on Days $0,3,5,7,8$ and 9.

\section{Collection of endometrial tissues}

On Day 9, endometrial tissue samples were obtained by an endometrial biopsy knife as described by Nielson (7). The endometrial tissues samples were removed by fine forceps and immersed in a microcentrifuge tube containing 30 $\mathrm{mm}$ of the lysis buffer supplemented with mercaptoethanol to quantify the expression of mRNAs of estrogen receptor alpha $(\mathrm{ER} \alpha)$ gene in the endometrium.

\section{$R T-{ }_{q} P C R$ assay for ER gene expression}

Total RNA was extracted from endometrial biopsy (30 mg) using RNA isolation kit (Thermo-scientific, fermentas Ko731) according to the manufacturer's instructions. The concentration of the total RNA was measured using Nanodrop Spectrophotometer. To obtain cDNA, the total RNA (1 $\mu \mathrm{g})$ was reverse transcribed using reverse transcription kits (Thermo-scientific, fermentas \# EP0451 according to the manufacturer's instructions).

Quantifying of mRNA for ER $\alpha$ in the three protocols was determined by quantative RTPCR using SYBR Green with GAPDH as an internal control reference. The isolated cDNA was amplified using 2x Maxima SYBER Green/Rox qPCR Master Mix (Thermo-scientific, USA, \# K0221) and gene specific primers according to the manufacturer's instructions.

The primers for $\mathrm{ER} \alpha$ gene were; 5'GAAGTGGGCATGATGAAAGG-3' forward and AAGGTTGGCACGTCTCATGT reverse and for GAPDH gene were 5'- CCTGGAGAAACCTGCCAAGT-3' forward and 5'GGTAGAAGAGTGAGTGTCGCT-3' reverse. The primer for $\mathrm{ER} \alpha$ receptor gene was 
designed using web based tool (http://www.genome.wi.mit.edu/egiin/primer/primer3www. egi) on the basis of published buffalo sequences to ensure that the primer sequence is unique for the template sequence. Amplicon sequence identity was confirmed with NCBI Blast tool software (Blast http://www.Blast.ncbi.nlm. nih.gov/Blast.egi). The reactions were conducted in a final volume of $25 \mu \mathrm{L}$ using $12.5 \mu \mathrm{L}$ of 2x Maxima SYBER Green/ Rox qPCR Master MIX, $1 \mu \mathrm{L}$ of each primer (forward and reverse), $3 \mu \mathrm{L}$ of cDNA (10-20 ng/ $\mu \mathrm{L})$ and $7.5 \mu \mathrm{L}$ of water nuclease free. The protocol conditions included initial denaturation at $95^{\circ} \mathrm{c}$ for 10 minutes and 40 cycles with denaturation at $95^{\circ} \mathrm{c}$ for $15 \mathrm{sec}$, annealing at $60^{\circ} \mathrm{c}$ for $30 \mathrm{sec}$ and extension at $72^{\circ} \mathrm{c}$ for $30 \mathrm{sec}$. The relative expression levels of target gene (ER $\alpha$ receptors) were calculated by using the $-\Delta \Delta C T$ method (20). The house keeping gene (GHPDH) was used as the normalizing reference gene. The cycle threshold $(\mathrm{Ct})$ values calculated for target gene were normalized against reference gene. The St-ovsync (control) group was used as calibrator, while CIDR-sync and Insulin- were considered as test groups for both target and references genes. The mean cycle threshold $(\mathrm{Ct})$ values were used to calculate $\Delta \mathrm{CT}$ for both target and reference genes in each of test and control groups by the following equation:

$\Delta \mathrm{CT}$ (test) $=\mathrm{Ct}$ (target in test groups) $-\mathrm{Ct}$ (ref in test groups)

$\Delta \mathrm{CT}$ (calibrator) $=\mathrm{Ct}$ (target in control) $\mathrm{Ct}$ (ref. in control).

Then $\Delta \mathrm{Ct}$ of the test genes were normalized to the $\Delta \mathrm{Ct}$ of the calibrator:

$\Delta \Delta \mathrm{Ct}=\Delta \mathrm{Ct}$ (test) $-\Delta \mathrm{Ct}$ (calibrator)

The fold change of the relative gene expression was calculated as follows:

Fold change $=\left(2^{-\Delta \Delta C t}\right)$.

Blood sampling and hormonal assay:

Blood sampling

Blood samples were collected by jugular vein puncture on the Days $0,3,5$ and 9. The samples were centrifuged at $3000 \mathrm{rpm}$ for 15 min. The harvested sera were stored at $-20^{\circ} \mathrm{C}$ until estrogen and progesterone assays.

Serum progesterone assay

The serum $\mathrm{P}_{4}$ concentrations were measured by radioimmunoassay using RIA kit (Beckman coulter RIA progesterone IMMUTECH, S.r.o Radiova 1-10227 Prague - Czech Republic) according to the manufacturer's instructions described in the catalog enclosed with the kit. The inter- and intra- assay coefficients of variations were 8.66 and 8.15 respectively. The average sensitivity was $9.58 \mathrm{pg} / \mathrm{ml}$.

\section{Serum estradiol assay}

The serum E2 concentrations were estimated by radioimmunoassay using estradiol kit (Beckman coulter RIA Estradiol; IMMUNTECH, s.r.o Radiova 1-10277 Prauge - Czech Republic) according to manufacturer's instructions described in the catalog enclosed with the kit. The inter- and intra- assay coefficients of variations were 14.5 and 14.4 respectively. The average sensitivity was $9.58 \mathrm{pg} / \mathrm{ml}$.

\section{Serum insulin assay}

The serum insulin concentrations were estimated using an IMMUNORADIOMETRIC kit (Insulin (e) IMRA kit; IMMUNOTECH, s.r.o Radiova 1-10227 praque- Czech Republic) according to the manufacturer's instructions described in the catalog enclosed with kit. The inter- and intra- assay coefficients of variations were $8.3 \%$ and $5.6 \%$ respectively. The average sensitivity was $4.55 \mathrm{ng} / \mathrm{ml}$.

\section{Reproductive management}

Buffaloes were inseminated at $16 \mathrm{~h}$ after the $2^{\text {nd }} \mathrm{GnRH}$ treatment (FTAI) with frozenthawed semen. On Day 30 post TAI, buffaloes were examined by transrectal US of their uteri for pregnancy diagnosis. Conception rates were calculated by dividing the number of buffaloes gets pregnant on the total number of buffaloes submitted to applied ovsync protocols TAI programs in the current study. 


\section{Statistical analysis}

All data, except conception rates, were presented as means \pm SEM. The statistical significance of differences was tested by the analysis of variance (ANOVA) followed by Bonferroni's multiple comparison test using Graphpad prism ver. 6. 0 for Mac (Graphpad software. San Dieogo, USA). Chi-Square analysis was used to compare the conception rates among the three protocols.

\section{Results}

\section{Ultra sound-Measured UWT}

On Day 0, the US-measured UWT did not differ $(\mathrm{P}>0.05)$ among St-ovsync, CIDR-sync and Insulin-sync in either eventually diagnosed pregnant (EDP) buffaloes or eventually diagnosed non pregnant (EDnP) buffaloes. It was observed that while the UWT decreased $(\mathrm{P}<0.05)$ in the CIDR-sync compared with either St-ovsync or Insulin-sync in EDP buffaloes, it did not differ among the 3 protocols in EDnP buffaloes on either of the $3^{\text {rd }}$ or $5^{\text {th }}$ day. Within each protocol, the UWT did not differ $(\mathrm{P}>0.05)$ between EDP and EDnP buffaloes in all the investigated days (Table, 1).

\section{Serum progesterone concentrations on the}

Days 0, 3 and 5

On the Days 0 and 5 , the serum $\mathrm{P}_{4}$ concentrations did not differ among the three protocols neither in EDP nor EDnP buffaloes. In contrary, on Day 3, it increased $(\mathrm{P}<0.05)$ in EDP and EDnP buffaloes in CIDR-sync compared with either St-ovsync or Insulin-sync (Table 1).

The uterine wall thickness on Day 9

The UWT did not differ $(\mathrm{P}<0.05)$ between either EDP or EDnP buffaloes on Day 9 as well as among EDnP buffaloes on Day 7. However, the UWT decreased $(\mathrm{P}<0.05)$ in EDP buffaloes in CIDR-sync compared with either St-ovsync or Insulin-sync group on Day 7 (Table, 2).

Serum estradiol concentration on the Day 9

In EDP buffaloes, serum $\mathrm{E}_{2}$ concentration on Day 9 showed a decrease $(P<0.05)$ in CIDRsync compared with either Stovsync or Insulinsync. In EDnP buffaloes, it showed nonsignificant $(\mathrm{P}>0.05)$ variations among the three protocols.

\section{Serum insulin concentration on Day 9}

The serum insulin concentration on Day 9 increased $(\mathrm{P}<0.05)$ in both EDP and EDnP buffaloes in Insulin-sync compared with either St-ovsync or CIDR-sync group (Table 2).

\section{Estrogen receptor (ER) gene expression}

The expression of $E R \alpha$ gene was upregulated $(\mathrm{P}<0.05)$ in insulin-sync protocol compared with St-ovsync. Also the expression was upregulated in CIDR-sync compared with St-ovsync (Figure 1) regardless the buffaloes were EDP or EDnP. There was nonsignificant difference between insulin-sync and CIDRsync. Relative to the St-ovsync, the fold change of 2.81 and 2.45 were recorded for the upregulation of $E R \alpha$ gene expression in the Insulin-sync and CIDR-sync respectively (Figure 1).

\section{The fertility response}

Pregnancy diagnosis on Day 30 post- TAI revealed that $5 / 12(41.66 \%) ; 6 / 12(50 \%)$ and $8 / 12(66.67 \%)$ buffaloes were diagnosed pregnant in St-ovsync, CIDR-sync and Insulin-sync protocols respectively (Figure 2). 
Table 1: Ultrasound-measured UWT and serum $\mathrm{P}_{4}$ concentrations in EDP and EDnP buffaloes in Stovsync, CIDR-sync and Insulin-sync protocols on Days 0, 3 and 5

\begin{tabular}{|c|c|c|c|c|c|c|}
\hline \multirow[t]{3}{*}{ Parameter } & \multicolumn{6}{|c|}{ Synchronization protocols } \\
\hline & \multicolumn{2}{|c|}{ St-Ovsync } & \multicolumn{2}{|c|}{ CIDR-Sync } & \multicolumn{2}{|c|}{ Insulin-Sync } \\
\hline & EDP & $\mathrm{EDnP}$ & EDP & EDnP & EDP & EDnP \\
\hline \multicolumn{7}{|l|}{ UWT (mm) } \\
\hline Day 0 & $42 \pm 0.02$ a & $42 \pm 0.01^{\mathrm{d}}$ & $41 \pm 0.02$ a & $41 \pm 0.03 \mathrm{~d}$ & $42 \pm 0.01$ a & $45 \pm 0.01 \mathrm{~d}$ \\
\hline Day 3 & $45 \pm 0.02$ a & $40 \pm 0.01^{\mathrm{d}}$ & $34 \pm 0.01 \mathrm{~b}$ & $39 \pm 0.02^{\mathrm{d}}$ & $41 \pm 0.01$ & $38 \pm 0.02 \mathrm{~d}$ \\
\hline Day 5 & $42 \pm 0.03 \mathrm{a}$ & $42 \pm 0.01^{\mathrm{d}}$ & $32 \pm 0.01 \mathrm{~b}$ & $38 \pm 0.03^{\mathrm{d}}$ & $41 \pm 0.01$ a & $45 \pm 0.02 \mathrm{~d}$ \\
\hline \multicolumn{7}{|c|}{ Serum $\mathrm{P}_{4}$ concentration $(\mathrm{ng} / \mathrm{ml})$} \\
\hline Day 0 & $3.41 \pm 0.83 b$ & $1.91 \pm 0.29 \mathrm{e}$ & $3.84 \pm 0.66^{b}$ & $2.55 \pm 0.28^{\mathrm{e}}$ & $3.73 \pm 0.98^{b}$ & $2.00 \pm 0.34 \mathrm{e}$ \\
\hline Day 3 & $3.58 \pm 0.62 b$ & $3.26 \pm 0.67^{\mathrm{e}}$ & $6.11 \pm 0.39^{a}$ & $6.39 \pm 1.01^{\mathrm{d}}$ & $3.49 \pm 0.51^{b}$ & $3.26 \pm 0.52$ \\
\hline Day 5 & $3.25 \pm 0.15^{b}$ & $4.05 \pm 0.17 \mathrm{e}$ & $5.95 \pm 1.39^{b}$ & $5.14 \pm 0.57^{\mathrm{e}}$ & $3.04 \pm 0.64^{b}$ & $3.98 \pm 0.30^{\mathrm{e}}$ \\
\hline
\end{tabular}

Within the same row, values carrying small letters from a to $\mathrm{c}$ in case of EDP and from (d to f) in case of EDnP buffaloes are different at $\mathrm{P}<0.05$. Within the same treatment group, values carrying asterisk are different at $\mathrm{P}<0.05$ between EDP and EDnP buffaloes.

Table 2: Ultrasound - measured UWT on Days 7, 8 and 9 and serum concentrations of $\mathrm{E}_{2}$ and insulin on Day 9 in St-ovsync, CIDR-sync and Insulin-sync protocols

\begin{tabular}{lcccccc}
\hline Parameter & \multicolumn{5}{c}{ Treatment protocol } \\
& $\begin{array}{r}\text { St-Ovsync } \\
\text { EDP }\end{array}$ & EDnP & $\begin{array}{c}\text { CIDR-Sync } \\
\text { EDP }\end{array}$ & EDnP & $\begin{array}{c}\text { Insulin-Sync } \\
\text { EDP }\end{array}$ & EDnP \\
\hline UWT (mm) & & & & & \\
Day7 & $42 \pm 0.02^{\mathrm{a}}$ & $42 \pm 0.01^{\mathrm{d}}$ & $33 \pm 0.01^{\mathrm{b}}$ & $35 \pm 0.3^{\mathrm{d}}$ & $43 \pm 0.02^{\mathrm{a}}$ & $44 \pm 0.05^{\mathrm{d}}$ \\
Day 8 & $43 \pm 0.04^{\mathrm{a}}$ & $44 \pm 0.01^{\mathrm{d}}$ & $35 \pm 0.02^{\mathrm{a}}$ & $36 \pm 0.02^{\mathrm{d}}$ & $45 \pm 0.02^{\mathrm{a}}$ & $41 \pm 0.04$ \\
Day 9 & $34 \pm 0.02^{\mathrm{a}}$ & $50 \pm 0.03$ & $34 \pm 0.02^{\mathrm{b}}$ & $49 \pm 0.04^{\mathrm{d}}$ & $43 \pm 0.03^{\mathrm{a}}$ & $41 \pm 0.04^{\mathrm{d}}$ \\
Serum estradiol concentration $(\mathrm{pg} / \mathrm{ml})$ & & & & \\
Day 9 & $17.3 \pm 1.55^{\mathrm{a}} 9.43 \pm 1.23^{\mathrm{d}}$ & $12.1 \pm 1.45^{\mathrm{b}}$ & $9.65 \pm 2.11^{\mathrm{d}}$ & $22.26 \pm 1.31^{\mathrm{a}}$ & $12.13 \pm 1.90^{\mathrm{d}}$ \\
Serum insulin concentration $(\mathrm{ng} / \mathrm{ml})$ & & & & \\
Day 9 & $7.18 \pm 1.85^{\mathrm{b}} 5.79 \pm 2.56^{\mathrm{e}}$ & $6.00 \pm 0.72^{\mathrm{e}}$ & $6.00 \pm 0.72^{\mathrm{e}}$ & $32.13 \pm 2.64^{*}$ & $15.13 \pm 2.21^{\mathrm{d}}$ \\
\hline
\end{tabular}

$\mathrm{EDP}=$ eventually diagnosed pregnant; $\mathrm{EDnP}=$ eventually diagnosed non-pregnant. Within the same row, values bearing different letters from a to $b$ in case of EDP buffaloes and from $\mathrm{d}$ to e in case of EDnP buffaloes were different at $(\mathrm{P}<0.05)$. Within the same protocol, values bearing asterisk were different at $\mathrm{P}<0.05$ between EDP and EDnP buffaloes.

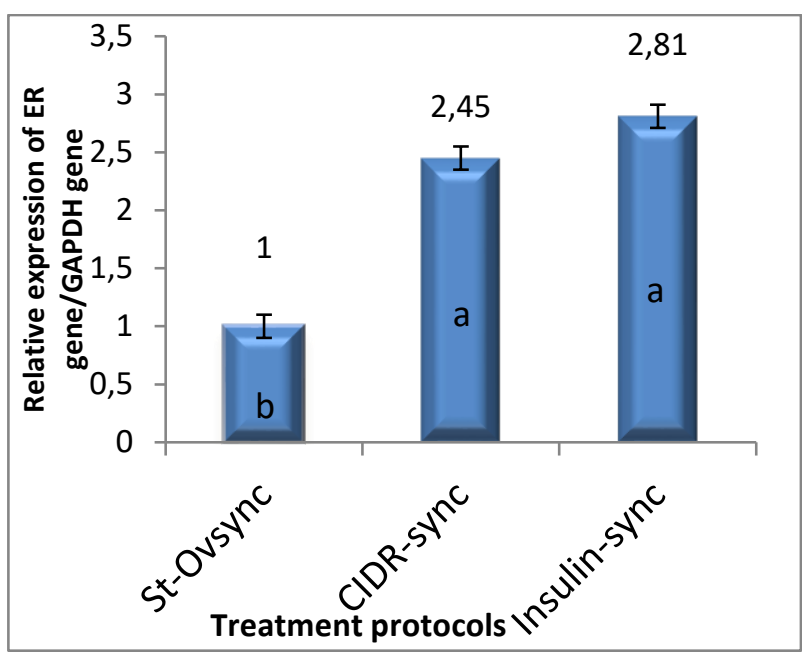

Figure 1: Oestrogen receptor alpha $(E R \alpha)$ gene expression in insulin-sync and CIDR-sync groups relative to St-ovsync shown as fold changes $\left(2^{-\Delta \Delta c t}\right)$. Relative to the St-ovsync (fold change $(\mathrm{Fc})=1$ ), the fold changes of 2.81 and 2.45 represented the upregulation of $E R \alpha$ gene in Insulin-sync and CIDR-sync groups respectively

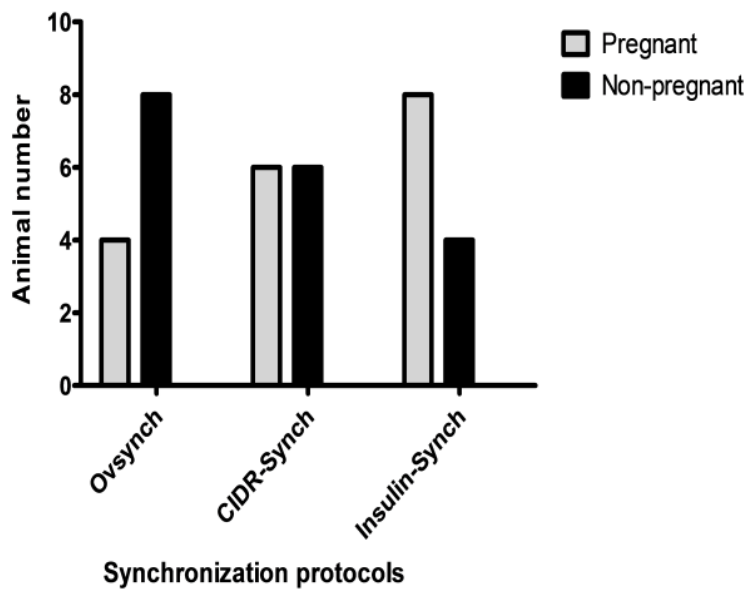

Figure 2: The conception rates on Day 30 post-TAI in buffaloes treated with St-ovsync, CIDR-sync and In sulin-sync. The conception rate was 5/12 (41.66 \%); 6/12 $(50 \%)$ and 8/12 (66.67 \%) in St-ovsync, CIDR- sync and Insulin-sync respectively 


\section{Discussion}

The present work aimed to study the uterine morphometry in terms of us-measured UWT in relation to steroid hormones profiles and endometrial oestrogen receptors in modified ovsync programs in buffaloes. Since endometrial growth and regression are synchronized with ovarian function through changes in circulating and/or local levels of oestrogen and progesterone $(21,4)$, ultrasound measuring of the uterine wall thickness, simple and reproducible technique, can be used to evaluate steroid hormone induced uterine environment changes (22).

On the day 3 and 5, the decrease in the UWT in the buffaloes eventually diagnosed pregnant (EDP) in CIDR-Sync compared with either StOvsync or Insulin-sync may be attributed to the increase in the serum progesterone concentrations at $p<0.05$ and $p>0.05$ on the days 3 and 5 respectively. Taking into account the similarity between the diestrous phase in the estrous cycle and short luteal phase, 2-7 days, in an ovsync protocol (Ref), the reduced UWT, recorded on the days 3 and 5 in the current study, came in line with (23) who reported that the uterine horns had minimal thickness, minimal luminal fluid and maximal horn curl during the period extending from $3^{\text {rd }}$ to $16^{\text {th }}$ day of the oestrous cycle. Sajjan (2014) (23) reported that the thickness of the endometrium, (most responsive layer of the uterine wall to the changes in the serum steroid hormones concentrations) decreased from 5.47 to $5.06 \mathrm{~mm}$ with the increase in the serum $\mathrm{P}_{4}$ concentration from 0.76 to $1.08 \mathrm{ng} / \mathrm{ml}$ in cows. In the same respect, Jimenez-Krassel et al (2009) (24) attributed the decrease in the endometrial thickness to the increase in the circulating $\mathrm{P}_{4}$ concentration

The non-significant variations in the UWT among EDP buffaloes on Day 0 as well as among EDnP buffaloes may be explained in the light of non-significant variations in the serum $\mathrm{P}_{4}$ concentrations on the respective days.

On Day 9, matching the serum $\mathrm{E}_{2}$ concentrations with UWT in case of EDP buffaloes revealed that the serum $\mathrm{E}_{2}$ concentrations, being high, were nearly consistent with respective UWT in case of either ST-ovsync or Insulin- sync but not in CIDR-sync. Conversely in $\mathrm{EDnP}$ buffaloes, it was inconsistent with respective UWT in all of three groups. In the EDP buffaloes, then insignificant increase in the UWT in the insulin-sync protocol compared with either ovsync or CIDR- sync may be explained in the light of increase in the respective serum E2 concentration in the insulin-sync compared with its counterpart value in case of either St-ovsync or CIDR - sync protocol. However, the increase in $\mathrm{E}_{2}$ receptors in CIDRsync compared with $\mathrm{St}-$ ovsync may increase the response of the endo- metrium, which is the main responder part of the uterine wall, to relatively low serum E2 levels in CIDR- sync thereby increasing UWT that became comparable to its counterpart value in case EDP buffaloes in St-ovsync. In line with this explanation, Xia and Goff (25) reported that the number of endometrial receptors determines the sensitivity of the uterus to the steroid stimulation.

The increase in the concentration of serum $\mathrm{E}_{2}$ in Insulin-sync compared with the other two groups may be due to stimulatory effect of insulin on the steroidogenic activity of the largest follicle. The exogenous insulin increase both follicular growth and steroidogenic activity in cows (26), buffaloes (27) and goats (28). In CIDR-sync, the lower serum E2 concentration in EDP buffaloes on Day 9 compared with either St-ovsync or Insulin- sync may be attributed to the presence of persistent follicles that bypassed the effect of the first GnRH and continued to grow and produce $\mathrm{E}_{2}$ at lower rates under the effect of low tonic level of LH induced by the negative feedback mechanism of P4 released from CIDR until Day 7 (Day of CIDR removal). Some of these persistent follicles continued to produce $\mathrm{E}_{2}$ at the previous lower level until Day 9. However, an interval of $48 \mathrm{~h}$ (from Day 7 to 9) is not sufficient for the persistent follicle to survive $\mathrm{P}$ 4-induced low tonic level of LH during the previous 7 days, thus their steroidogenic activity became compromised. In line with this explanation, Cerri et al (2010) (29) found that the tonic levels of LH were lower in cows having high serum $\mathrm{P}_{4}$ concentrations on Day 5 of CIDR-sync protocol. 
On the other hand, Cerri et al, (29) reported that the decreased concentrations of $\mathrm{P}_{4}$ during synchronization protocol resulted in high basal LH concentrations, faster growth of dominant follicle (DF) and higher circulating E2. In spontaneous estrous, a proestrous period of 3-4 days may be sufficient for resumption of proper tonic level of $\mathrm{LH}$ that stimulates proliferative and steroidogenic activity of the DF. In accordance with this suggestion, Bridges et al, (2010) (30) reported that reducing the duration of proestrous in cows, induced to ovulate small follicles, resulted in decreased serum preovulatory E2 $(30,31)$. Nonetheless, Cerri et al. (29) found concentration was lesser from day 5 to 9 of CIDR-sync protocols in cows having high compared with those having low serum $\mathrm{P}_{4}$ that the serum $\mathrm{E}_{2}$ concentrations.

The benefit of studying the abundance of $\mathrm{ER} \alpha$ in these three Ovsync protocols comes from the fact that the changes in the uterine morphometry in response to $\mathrm{E}_{2}$ are an outcome of the interaction of the local/peripheral E2 concentration with its receptors in the uterine tissues. Okumu et al. (11) reported that not only the availability of a steroid hormone in the peripheral circulation is adequate to produce the desired effect on the uterus but binding to their specific nuclear receptors is critical.

In the current study, the expression pattern of ER $\alpha$ in the endometrial biopsy is compatible with serum $\mathrm{E}_{2}$ concentrations in either Insulinsync or St-ovsync but not with CIDR- sync to some extent. The higher $\mathrm{E}_{2}$ levels in case of Insulin-sync and St-ovsync came in agreement with Sunderland et al (1994) (32) who reported that the expression pattern of ER $\alpha$ is consistent with the circulating concentration of $\mathrm{E}_{2}$ during oestrous cycle.

In the same respect, Clark et al and Mann et al $(33,34)$ detected the highest level of ER $\alpha$ and PRs mRNA at the time of oestrous and concluded that the stimulatory effect of $\mathrm{E}_{2}$ on sex hormone receptors expression. Also Spencer and Bazer (35) reported that $\mathrm{E}_{2}$ as well as those for $\mathrm{P}_{4}$ and the functions at the cellular level to increase the rate of mitosis and tissue oedema (15), a finding which explained the increased UWT in either of Insulin-sync or St-ovsync compared with CIDR-sync. However, the reduced UWT in the CIDR-sync may result from the delayed recovery of UW from the effect of high $\mathrm{P}_{4}$ concentration during period of CIDR insertion. However, the abundance of ER $\alpha$ was higher in CIDRsync compared with St-ovsync but the $\mathrm{E}_{2}$ concentration was higher $(\mathrm{P}>0.05)$ in St-ovsync compared with CIDR-sync. Although the $\mathrm{E}_{2}$ concentration was lower $(\mathrm{P}>$ 0.05) in CIDR-sync compared with St-ovsync, the abun- dance of ERs in CIDR-sync was higher than St-Ovsync. This may be attributed to the pre exposure of the uterus in case of CIDR-sync to higher $\mathrm{P}_{4}$ concentration during the period of CIDR insertion. This explanation may be supported by the results of Shimizu et al (36) who reported that $\mathrm{E}_{2}$ and $\mathrm{P}_{4}$ provoke transcriptome changes within the endometrium, with the response to $\mathrm{E}_{2}$ being greater when the uterus was preexposed to higher $\mathrm{P}_{4}$.

\section{Conclusion}

It is concluded that modifying the St-ovsync by including $\mathrm{P}_{4}$ through CIDR-insertion from Day 0 to 7 or treatment with insulin on Days 7, 8 and 9 could modulate uterine morphometry, thereby improving fertility outcome of ovsync protocols. Further studies are required in the future to study the effects of the $\mathrm{P}_{4}$ or insulin-induced transcriptome changes in the uterus of cows treated with modified $\mathrm{P}_{4}$ or insulin-modified ovsyncs on the uterine histotrophs secretion that may explain its beneficial effects on the animal fertility.

\section{Conflict of interest}

The authors declare that they have no conflict of interest.

\section{References}

1. Bridges G A, Mussard M L, Hessler L A, Day $\mathrm{M}$ L. Comparison of follicular dynamics and hormone concentration between 7-day and 5-day cosync + CIDR program in primiparous beef cows. Theriogenology2014; 81: 632-8.

2. Mesquita F S, Pugliesi G, Scolari S C, Franca M R, Ramos R S, Olivera M, Papa P C, Bressan F F, Meirelles F V, Silva L A, Nogueira G P, Membrive C M B, Binelli M. Manipulation of sex steroi- 
dal mileu affects endometrial but not luteal gene expression in early diestrous Nelore cows. Theriogenology 2015; 81: 861-9.

3. Araujo E R, Sponchiado M, Pugliesi G, Hoeck V V, Mesquita F S, Membrive C M B, Binelli M. Spatio-specific regulation of endocrine responsive gene transcription by preovulatory profiles in the bovine reproductive tract. Reprod Fertil Dev 2015; 28: $1533-44$.

4. Souza A H, Narciso C D, Batista E O S, Carvalho $P$ D, Wiltbank M C. Effect of uterine environment on embryo production and fertility in cows. AnimReprod2014; 11: 159-67.

5. Hericks D M, Hill J R, Dickey J F, Lamond D R. Plasma hormone levels in beef cows with induced multiple ovulation. J Reprod Fertil 1973; 35: 225-33.

6. Pierson R A, and Ginther, O J. Ultrasonographic appearance of the bovine uterus during the estrous cycle. J A M Vet Assoc 1987; 190: 9951001 .

7. Bonafos L D, Kot K, Ginther O J. Physical characteristics of the uterus during the bovine estrous cycle and early pregnancy. Theriogenology 1995; 43:713-21.

8. Wiltbank M, Lopez H, Sartori R, Sangsritavong S, Gumen A. Changes in reproductive physiology of lactating dairy cows due to elevated steroid metabolism. Theriogenology2006; 65: 17-29.

9. Perry G A, Smith M F, Lucy M C, Green J A, Parks T E, Mac-Neil, M D, Roberts J A, Geary T W. Relationship between follicular size at insemination and pregnancy success. Proc Natl Acad Sci USA 2005; 102: 5268-73.

10. Bridges G A, Mussard M L, Pate J L,Ott T L, Hansen TR, Day M L. Impact of preovulatory estradiol concentration on conceptus development and uterine gene expression. Anim Reprod Sci 2012; 133: 16-26.

11. Okumu L A, Forde N, Fahy A G, Fitz Patrick E, Roche J F, Crowe MA, lonergan P. The effect of elevated progesterone and pregnancy status on $\mathrm{m}$ RNA expression and localization of progesterone and oestrogen receptors in the bovine uterus. Reproduction 2010 ;104: 143-3.

12. Kimmins S, Maclaren L A. Oestrous cycle and pregnancy effects on the distribution of oestrogen and progesterone receptors in bovine endometrium. Placenta 2001; 22: 742-8.

13. Ing $\mathrm{N} \mathrm{H}$, Tornesi M B. Etrogen Upregulates estrogen receptors and progesterone receptor gene expression in specific ovine uterine cells. Biol Reprod 1997; 56: 1205-15.
14. Meikle A, Sahlin L, Ferraris A, Masironi B, Blanc J E, Rodriguez-Irazoqui M, Rodriguez-Pinon M, KindahiH, Forsberg M. Endometrial mRNA expression of estrogen receptors and insulin-like growth factor-1 (IGF-1) throughout the bovine oestrous cycle. Anim Reprod Sci 2001; 68: 45-56.

15. Tibbetts T A, Conneely O M, O’Malley B W. Progesterone via its receptors antagonizes the proinflamatory activity of estrogen in the mouse uterus. Biol Reprod 1999; 60: 1158-65.

16. Souza A H, Ayres H, Ferreira R M, Wiltbank M C. A new pre synchronization system (Doubleovsync) increases fertility at first postpartum timed AI in lactating dairy cows. Theriogenology 2008; 70: 208-15.

17. Herlihy M M, Giordano J O, Souza A H, Ayres H, Ferreira R M, Keskin A, Nascimento A B, Guenther J N, Gaska J M, Kacuba S J, Crowe M A, Butler S T, Wiltbank M C. Pre synchronization with double ovsync improves fertility at first postpartum artificial insemination in lactating dairy cows. J Dairy Sci 2012; 95: 7003-14.

18. Souza A H, Silva E P B, Cunha A P, Gumen A, Ayres H, Brusveen D J, Guenther J N, Wiltbank M C. Ultrasonographic evolution of endometrial thickness near timed A.I as a predictor of fertility in high producing dairy cows. Theriogenology 2011; 75: 722-33.

19. Baerwald A R, Pierson R A. Endometrial development in association with ovarian follicular waves during the menstrual cycle. Ultrasound $\mathrm{Ob}-$ stet Gynec 2004; 24:453-60.

20. Livak K J, Slimittgen T D. Analysis of relative gene expression data using real time quantative PCR and 2- $\Delta \Delta$ ctmethod. A new mathematical method. Methods 2001; 25: 402-8.

21. Johnson M L, Redmer D H, Reynolds L P. Effect of ovarian steroids on uterine growth, morphology and cell proliferation in ovariectomized, steroid-treated ewes. Biol Reprod 1997; 57: 58896.

22. Delisle M F, Villeneuve M, Boulvain M. Measurement of endometrial thickness with transvaginal ultrasonography: is it reproducible J Ultrasound Med 1998; 17: 781-4.

23. Sajjan S. Studies on the ultrasonographic characterization of endometrial thickness in estrus cycle of cows. M V Sci thesis, Univ BIDAR India 2014.

24. Jimenez-Krassel F, Folger J K, Ireland J L H, Smith G W, Hou X, Davis J F, Longergan P, Evans $\mathrm{A} d$, Ireland $\mathrm{J} J$. Evidence that high variation in ovarian reserves of healthy young adult has a negative impact on the corpus luteum and endometrium 
during oestrous cycles in cattle. Biol Reprod 2009; 80: $1272-81$.

25. Xiao C W, Goff A K. Hormonal regulation of oestrogen and progesterone receptors in cultured bovine endometrial cells. J Reprod Fertil 1999; 115: 101-9.

26. Simpson R D, Chase J R C C, Spicer L J, Vernon, R K I, Hammond A C X, Rae D O. Effect of exogenous insulin on plasma and follicular insulin-like growth factors-1, growth factor binding protein activity, follicular estradiol and progesterone and follicular growth in super ovulated Angus and Brahman cows. J Reprod Fertil 1994; 102: 483-2.

27. Ramoun A A, Osman K T, Darwish S A, Karen A M, Gamal M H. Effect of pretreatment with insulin on the response of buffaloes with inactive ovaries to gonadotropin releasing hormone against treatment in summer. Reprod Fertil Dev 2007; 19: $351-5$.

28. Suguna K, Mehorta S, Agarwal S K, Hoqueh M, Shanker U, Singh S K, Varshney V P. Effect of exogenous insulin administration on ovulation function, embryo/fetal development during pregnancy in goats. Anim Reprod Sci 2009; 111:202-13.

29. Cerri R L A, Chebel R C, Rivera F, Narciso C D, Olivera R A, Amstalden M, Baez-Sandoval G M, Olivera L G, Tahatcher W W, Santos J E. Concentration of progesterone during the development of the ovulatory follicle: II. Ovarian and uterine responses. J Dairy Sci 2011; 94: 3352-65.
30. Bridges G A, Mussard M L, Burke C R, Day $\mathrm{M} \mathrm{L}$. Influence of the length of proestrous on fertility and endocrine function in female cattle. AnimReprodSci2010; 117:208.

31. Mussard M L, Burke C R, Behlke K J, Gasser C L, Day M L. Influence of premature induction of a luteinizing hormone surge with gonadotrophin releasing hormone on ovulation, Luteal function and fertility in cattle. J Anim Sci 2007; 85:937-3.

32. Sunderland S J, Crowe M A, Boland M P, Roche J F, Ireland J J. Selection, dominance and atresia of follicles during the oestrous cycle of heifers. Journal of Reprod Fertil 1994; 101:547-56.

33. Clark J H, Schrader W T, O’Malley B W. Mechanisms of steroid hormones action. In: Wilson J D, Foster DW(Eds.), Williams Textbook of Endocrinology, 8th Edition Saunders, Philadelphia pp 1992; 35-90.

34. Mann G E, Lamming G E, Robinson R S, Wathes D C. The regulation of interferon-production and uterine hormone receptors during early pregnancy. J Reprod Fertil 1999; 54: 317-28.

35. Spencer T E and Bazer F W. Temporal and spatial alterations in uterine estrogen receptor and progesterone receptor gene expression during the estrous cycle and early pregnancy in the ewe.Biology of Reproduction 1995; 53: 1527-43.

36. Shimizm T u s, Krebs S, Bauersachs H, Blum E, Wolf, Miyamoto A. Actions and interaction of progesterone and estrogen on transcriptome profiles of the bovine endometrium. Physiol Genomics 2010; 42:290-00. 